\title{
ДВА КЛІНІЧНІ ВИПАДКИ СИНДРОМУ ГІПЕРСТИМУЛЬОВАНИХ ЯЕЧНИКІВ
}

\author{
Б.М. Венцківський, І.Б. Венцківська, О.С. Загородня \\ Начіональний медичний університет імені О.О. Богомольия, кафедра \\ акушерства та гінекологї №1
}

\begin{abstract}
Синдром гіперстимульованих яєчників - ускладнення застосування допоміжних репродуктивних технологій, провідним проявом якого $\epsilon$ збільшення розмірів яєчників та транссудація вільної рідини в черевну порожнину за рахунок збільшення проникності судин мікроциркуляторного русла яєчників. Наслідком надмірної транссудації $\epsilon$ порушення електролітного балансу, підвищена здатність до тромбоутворення та інші розлади метаболізму, що можуть нести ризик для життя пацієнтки [1]. Частота синдрому в легкій його формі сягає $30 \%$ всіх пацієнток, що зазнали впливу екзогенних гонадотропних гормонів з метою стимуляції овуляції, проте клінічно значущі прояви синдрому супроводжують не більше 3\% всіх циклів індукції [2].
\end{abstract}

Залежновідчасупоявисимптомів виділяють ранню форму синдрому гіперстимульованих яєчників (виникає протягом 7 днів від введення екзогенних гормонів) та пізню (розвивається через 10 та більше днів від спроби індукції, його патогенез пов'язаний 3 максимальним викидом власних гонадотропних гормонів), саме їй властивий гірший прогноз. Крім того, особливе значення має спонтанний синдром гіперстимульованих яєчників, що виникає на тлі вагітності.

Причини розвитку клінічних проявів синдрому гіперстимульованих яєчників лежать в площині локального дисбалансу про- та протизапальних цитокінів, на думку інших дослідників $\epsilon$ результатом надмірного зростання концентрації реніну та кількості рецепторів до ангіотензину.

Пацієнтка Б., 32 роки, перебувала на обліку по вагітностіз терміну 9-10тижнів.Зачасспостереження до 30 тижнів патології вагітності виявлено не було, в 30 тижнів при виконанні планового ультразвукового дослідження виявлено збільшення розмірів яєчників до 90×69×84 мм правого та 118х69х84 мм лівого. Жодних специфічних для синдрому скарг пацієнтка на мала, за рештою показників перебіг вагітності неускладнений. Пологи відбулись в термін 41 тиждень, протягом 6 тижнів після пологів розміри яєчників поступово регресували.

Інше спостереження - пацієнтка М., 25 років, надійшла до гінекологічного відділення з ознаками гострого живота, в анамнезі - курс стимуляції овуляції. При виконанні лапароскопічного втручання - яєчники збільшені до 8 см в діаметрі, один 3 них містить кисту 3 розривом. Загальна крововтрата сягнула 1000 мл, в післяопераційному періоді виконано гемотрансфузію, на 5-й день - тест на вагітність негативний. Особливістю післяопераційного періоду став виразний набряк зовнішніх статевих органів.

Описані випадки демонструють, що походження синдрому гіперстимульованих яєчників не завжди ятрогенне, а результат його-не завжди сприятливий для настання та прогресування вагітності.

\section{ЛІТЕРАТУРА}

1. Kumar P., Sait S., Sharma A., Kumar M. Ovarian hyperstimulation syndrome. J Hum Reprod Sci. 2011 May; 4(2):70-5.

2. Delvigne $A$, Rozenberg S. Epidemiology and prevention of ovarian hyperstimulation syndrome (OHSS): a review. Hum Reprod Update. 2002 NovDec; 8(6):559-77.

3. Sridev S, Barathan S. Case report on spontaneous ovarian hyperstimulation syndrome following natural conception associated with primary hypothyroidism. J Hum Reprod Sci. 2013 Apr-Jun; 6(2): 158-161.

Дата надходження до редакції 08.10.2018 p. 